\author{
Gabriela HANUS, MA \\ University of Economics in Katowice, Faculty of Management \\ e-mail: gabriela.hanus@edu.uekat.pl
}

DOI: $10.15290 /$ oes.2018.01.91.17

\title{
FOOD MARKET INNOVATIONS AS A RESPONSE TO CONSUMER REQUIREMENTS: A REVIEW OF LITERATURE
}

\begin{abstract}
The aim of the paper is to discuss selected innovations created by food companies in response to consumer needs on the basis of secondary sources of information published in the years 2000-2017. As a result of the conducted studies, it was observed that modern consumers have busy lifestyles and are increasingly environment and health conscious. Therefore, they look for alternatives that will guarantee comfort, save time and help improve their health. In addition, more and more attention is focused on the emotions which accompany consumption. Therefore, in order to remain competitive, food industry companies are forced to study the market and implement innovative solutions adjusted to the preferences of consumers, such as convenience foods, functional foods, and special catering services.
\end{abstract}

Key words: innovations in food market, consumer needs, consumer food behavior

\section{Introduction}

In recent years, considerable changes have been observed in both the behaviors and needs of consumers as regards food. These changes have modified mainly the organization and the way that consumer markets are functioning, as well as the ways and forms in which the consumption needs of buyers are satisfied. A clear manifestation of these changes is the evolution of both the expectations and needs of individual consumers, which in the food market are reflected in the range of goods on offer, varying in terms of the attractiveness of retail points and forms of needs satisfaction. This is connected with the fact that the process of satisfying individual and collective needs, both basic and more sophisticated, material and non-material, has been transformed - as a result of the free flow of capital, people, goods and services, as well as technological advancement - into a complex process of seeking, shaping, selecting, and consuming multidimensional values that are chiefly identified with products. One characteristic feature of the multidimensional character of the consumption processes is the qualitative and quantitative development of product portfolios, brought about by the creation of product innovations in the market [Sojkin, 2009, p. 7]. 
The impact of environmental, social, demographic, and economic factors in combination with increasing ecological and health awareness and the desire to maintain a balance between professional life and leisure, and the search for new qualities ensuring the convenience of purchase and consumption, have led to a situation where people seek products and services that will meet their requirements. In response to consumer needs, food sector companies launch new products and services to meet their customers' expectations, i.e. convenience foods, functional foods, as well as special gastronomic services. They are regarded as innovations in the food market because they considerably differ from the currently available products by providing consumers with new, increased benefits related to the their present needs.

The aim of this paper, which has the character of a review, is to discuss (on the basis of secondary sources of information published in the years 2000-2017) convenience foods, functional foods, and selected gastronomic services as examples of food market innovations. The author investigates the requirements of consumers and selected factors which determine changes in their grocery needs, presenting new trends in nutrition behaviors, and also innovations on the food market, with particular attention to convenience and functional foods, as well as special gastronomic services. The author uses the method of literature review, especially focusing on the most recent reports published in reviewed scientific journals. The subjective scope of the paper comprises innovations in the food market and consumer needs, while the objective scope concerns the behavior of consumers and companies from the gastronomic sector, the spatial range of the discussed economy. The time period of the literature review encompasses the years 2000-2017.

\section{Selected factors behind changes in the grocery needs of consumers}

Numerous authors have attempted to define the notion of need. Gardocka-Jałowiec [Gardocka-Jałowiec, 2017, p. 6] defines it as a perceived state of lacking something, which at the same time triggers the motivation to act in order to achieve a satisfactory change of the experienced state. Żuchowski and Brelik [Z̈uchowski and Brelik, 2007, pp. 207-231] explain that needs appear when an individual feels the lack of a basic good.

In the context of this paper, it is necessary to emphasize that the proper functioning of the human organism requires the consumption of food. Therefore, nutrition needs are considered to be crucial and their satisfaction has a considerable impact on the occurrence of any other needs [Zalega, 2011, p. 119].

Krzyszton [Krzyszton, 2014, p. 236] observes that a need is a dynamic concept, which is subject to constant development on several levels. Changes of demographic, socio-cultural, economic and technological nature considerably modify the needs of consumers.

Tomaszewska et al. [Tomaszewska et al., 2014, pp. 293-294] note that the development of civilization observed within the last few decades has undeniably contributed to enhancing people's living standards and their well-being by improv- 
ing the quality of life and lengthening life expectancy. Nevertheless, it has also had a detrimental effect on the health of individuals. The changeability of environmental factors and lifestyles has led to the development of many diseases such as diabetes, cardiovascular conditions, cancer, or obesity.

Voinea [Voinea, 2011, pp. 127-138] emphasizes that the increasing number of health problems resulting, among other things, from excessive consumption of highly processed and genetically modified foods, has caused many consumers to perceive health as one of the most important factors that determine their consumption choices [Goetzke and Spiller, 2014, pp. 510-526]. Additionally, research conducted, e.g. by Maddock and Hill [Maddock and Hill, 2016, pp. 327-342], Saeed et al. [Saeed et al., 2015, p.27], or Richardson [Richardson, 2003, p. 96] provides evidence of the impact of diet on the mental state of individuals, which also motivates purchasers to seek food that meets their requirements.

On the other hand, the report "Home Cooking and Eating Habits: Global Survey Strategic Analysis"1 [Euromonitor International, 2012] implies that consumers increasingly tend to have meals at irregular intervals. Such factors as busy lifestyles, non-standard working hours, the growing number of one-person households, greater occupational activity of women, the phenomenon known as boomerang children, ageing societies, as well as the lack of basic cooking abilities boost the demand for convenience meals or eating out.

Therefore, contemporary consumers seek such alternatives that enable them to make the preparation of meals less time-consuming and use the saved time for work or relaxation, and economize on food products, while remaining relatively healthy [Babicz-Zielińska, Jeżewska-Zychowicz, and Laskowski, 2010, p. 142; Thompson and Moughan, 2008, pp. 61-73].

\section{Selected new trends in food behaviors of consumers: a review of recent research}

As regards the market of food products, one may observe, among others, the following phenomena: servitization, ecologization, rationalization, globalization, and ethnocentric consumption of food products that constitute the main impulses for producers to implement innovations in the food market.

Servitization of food consumption is a notable market trend. Adams et al. [Adams et al., 2015, p.2] have observed that eating out is becoming increasingly popular worldwide and has a considerable impact on the structure of household expenses. This tendency is particularly noticeable in China, Great Britain, France, Netherlands, the United States, and Norway. In Great Britain, in the years 20092012, expenditures on eating out rose by $7 \%$ ( $€ 11.40$ per person a week), while

1 The research that provided these conclusions was conducted in eight countries: United States, Brazil, Great Britain, Germany, France, India, China, and Japan. 
expenditures on take-away food increased by $11 \%$, which amounted to $€ 2.28$ on average per person a week. These expenditures constituted more than one fourth $(26 \%)$ of all the expenditures on food and alcohol-free beverages in the household budgets.

Globalization regarding the consumption of food products is manifested, e.g. in the fact that consumption patterns observed in one culture become popular in other cultures. This is exemplified by the growing appeal of fast food, which is becoming alternative or supplementary to consumption of home food [Gulbicka, Kwasek, 2007, p. 7]. Its popularity is still increasing, as has been noticed, among others, by Morse and Briskell [Morse and Briskell, 2009, pp. 173-179] as well as McLeanMeyinsse et al. [McLean-Meyinsse et al., 2015, pp. 23-30]. The authors stress that although such food is high in fat and calories, deficient in calcium, iron and fiber, thus increasing the risk of obesity and diabetes, consumers, especially young ones, admit that they eat it to excess. Mazurek-Łopacińska [Mazurek-Łopacińska, 2011, p. $53]$ notices that modern consumers crave diversity and seek new experiences, including culinary ones. Therefore, one may notice the increasing popularity of products from various national cuisines and various types of culinary festivals, street foods, as well as more sophisticated gastronomic services.

The globalization of food consumption patterns has caused a counter-reaction in the form of an intensification of ethnocentric behaviors among consumers, manifested in their attachment to local products. In accordance with the research conducted by Autio et al. [Autio et al., 2013, p. 556], the inhabitants of Finland are ready to pay more for food purchased directly from a farmer operating within $80 \mathrm{~km}$ from their place of residence. Some of them decide to grow plants in their gardens, allotments or on their balconies. Therefore, local patriotism in the food market is becoming a point of reference for marketing strategies created by food producers [Dziok, 2014, pp. 174-184]

In recent years, a considerably larger role is being played by the phenomena of the ecologization and rationalization of the consumption of food products. Sobczyk [Sobczyk, 2014, pp. 97-98] draws attention to consumers' increasing awareness of environmental protection and health issues, which has resulted in a search for products that meet their requirements even if they cost more [Muhammada and al., 2015, pp. 37-40]. High levels of ecological awareness have an impact on the purchasing decisions made by individuals. In particular, persons who become involved in environmental protection change their habits and more frequently purchase environmentally friendly products [Mańkowska-Wróbel, 2014, p. 143]. Rochocka [Rochocka, 2003, p. 187] observes that thanks to numerous educational campaigns promoting sensible and healthy lifestyles there is more criticism towards excessive consumption and numerous attempts are made to rationalize some spheres of life, including nutrition. These attitudes compel food producers to change production patterns into more environmentally friendly ones and to take into consideration ecological aspects in each phase of a product's lifecycle [Mańkowska-Wróbel, 2014, p. 143]. 


\section{Innovations in the food market}

Kowalczuk [Kowalczuk, 2009, p. 63] emphasizes that innovation is the key to competitiveness in each economic sector because it constitutes the driving force of the market, providing a tool for entrepreneurship and stimulating progress. Product innovations are an effect of new product development processes. Among the drivers of this process, the following should be distinguished:

- technological advancement,

- changes in the needs, expectations and preferences of customers,

- gradual shortening of the lifecycle of products that results from changes in the requirements of the market and technological changes which entail the necessity to offer new products,

- open foreign markets and increasing competitiveness on a global scale.

Szymańska [Szymańska 2012, p. 151] defines product innovations as introduction onto the market of a product whose purpose or technological properties considerably differ from the previously manufactured products or whose efficiency has been considerably enhanced and may ensure new or larger benefits for the consumer. On the other hand, Czupilowska [Czupilowska, 2014, pp. 138-139] quotes a definition of innovation from the third edition of the "Oslo Manual", which draws particular attention to the fact of introducing into economic activity a novelty, a considerable improvement of a product or service, whereas in the case of a product innovation, the use of new knowledge or the introduction of a combination of existing knowledge and technologies.

As regards the food market, a product innovation is a newly launched product, one with which consumers were not previously familiar; it can also denote a considerable modification (accepted by buyers) of a product in terms of its nutritional value, storage, preparation, or taste. Olejniczak [Olejniczak 2011, p. 88] has observed that the Polish market is characterized by a large number of product innovations which are neither interesting for consumers nor particularly revolutionary. The author adds that 'new' food products are usually marketed as 'new' thanks to modified packaging, consistency, form, or type of a previously existing product. According to the him, this may result from the non-uniform perception of the dimensions of the innovative character of food products, the traditional attitudes of consumers towards new products, a relative reluctance to purchase innovative food products, and low awareness among consumers of new food products on offer.

Sojkin [Sojkin, 2009, pp. 99-100] observes that the abundance of various dimensions of the innovativeness of food market products seems to confuse consumers, making it difficult for them to distinguish 'what is new'. A study conducted by the author shows that more than half of the respondents asked how they understood the concept of 'food product innovation' replied that a new product meant supplementing the product range by adding either new flavors or changing consistency, i.e. each modification of a product, or - according to a smaller group of respondents - the introduction of an entirely new product that had never been present in the market. One respondent in three considered a product innovation to 
be part of the marketing game and a reduction of unhealthy components. $28 \%$ of the respondents regarded the change of product packaging as a product innovation, whereas for one in four it meant adding new components to the product itself.

Of all the various product innovations in the food market, this study focuses on convenience foods, functional foods, and special gastronomic services.

\subsection{Convenience foods}

Convenience foods are defined in the subject literature as products and services that enable consumers to save time preparing meals, as meals that are either partly or entirely prepared by another party, or as all processed products, including readycooked meals, meat, soups, starters, pizza, patés etc. Convenience foods also include products that can be directly consumed or require minimal cooking, pre-prepared in a way that is convenient for buyers [Babicz-Zielińska, Jeżewska-Zychowicz and Laskowski, 2010, pp. 141-142]. Makała [Makała, 2013, p.106] provides a definition according to which it is food that is concentrated, pre-prepared and ready for direct consumption after short thermal treatment, e.g. defrosting or heating in the microwave oven at any time and in various circumstances, depending on one's activity and expectations. The food is accessible, properly packed, preserved and is either a ready meal or one of its components. Babicz-Zielińska et al. [Babicz-Zielińska, JeżewskaZychowicz and Laskowski, 2010, pp. 141-142] emphasize that all the aforementioned definitions have one element in common: minimal cooking time required.

Convenience food dates back to the turn of the $18^{\text {th }}$ and $19^{\text {th }}$ centuries, when the French inventor Nicolas Appert developed a way of sterilizing vegetables and meat that gave rise to the production of modern canned food. In the second half of the $19^{\text {th }}$ century, the number of products aimed at simplifying cooking grew, e.g. stock products or concentrates appeared. Also, the first factories producing chicory coffee or stock cubes were established. Initially, these products were used in extreme situations such as the war (in the form of dinner concentrates for the army) because they largely failed to meet the expectations of consumers. The progress of civilization (technological, in particular) as well as changes in social life (e.g. increased occupational activity of women) contributed to the dynamic development of convenience foods in the following years [Hanus, 2017, pp. 36-37].

Makała [Makała, 2002, pp.13-15] points to the very dynamic development of the convenience food market in many European countries (Netherlands, Great Britain, Germany) and in the USA. Forecasts show that this trend will continue in the nearest future. These products are becoming standard in the households of people who are very active professionally, in catering provided to railway and air passengers, in snack bars, and institutional catering. Additionally, networks of the so-called convenience shops are established that offer this kind of food, for example at petrol stations, as well as distribution systems which provide consumers with food ready for immediate consumption (e.g. pizza) [Makała, 2013, p. 109].

Pietrzak [Pietrzak, 2010, pp. 16-18] observes that the market of convenience food in Poland is listed among the most innovative and dynamic branches of the food processing industry. Among the most popular are poultry meat products, 
although their production was developed only at the turn of the 20th and 21st centuries. However, observation of these markets in other European countries, indicates that this type of meat is used in an appropriate way because it seems likely to gain even greater popularity among consumers. Every year, new convenient kinds of meat products, either new or modified ones, are introduced.

Makała [Makała, 2002, pp. 13-15] observes that the consumption of convenience foods on a similar or larger scale depends on such factors as freshness and high quality of products, as well as their taste, attractive appearance and safety.

Owing to the increasing requirements of consumers as regards the nutritional value of products, manufacturers of convenience food and trying to reduce the fat content and other potentially unwholesome substances in meat, dairy and other products [Krełowska-Kułas M., 2005, p. 144].

Freeze-dried products are an interesting type of convenience food. Their production involves freeze-drying that removes water from food while maintaining the biological, physical and chemical properties of the natural products [Kondratowicz, Burczyk, Janiak, 2009, p. 58]. They are used mostly in tourism.

Babicz-Zielińska, Jeżewska-Zychowicz and Laskowski [Babicz-Zielińska, Jeżewska-Zychowicz, Laskowski, 2010, pp. 141-153] conducted research concerning consumers' views on convenience food and their attitudes to it. This type of food was familiar to $82 \%$ of the respondents. Occupational activity, sex, and place of residence did not have a considerable impact on being familiar with it. It was the least known to the oldest of the respondents. Persons with higher education aged from 30 to 49 and with incomes exceeding 2,000 PLN that belonged to the group of specialists and managers bought it more often. Only $20 \%$ of the respondents did not agree with the statements that "convenience foods are good for health" and that "there are benefits from consuming them" ( $40 \%$ of the respondents agreed with both of the above). Nearly half of the respondents (48\%) did not see any risk in consuming this type of food. Most respondents agreed that the consumption of convenience foods had more benefits than risks. For 25\% of the interviewed persons, the health benefits and risks related to the consumption of convenience foods were neutral. More than half of the respondents declared a positive attitude towards convenience foods: these were young persons in particular. It was observed that it was single persons or small households that most frequently made use of products that facilitate the preparation of meals. Although they more often noticed the risk related to the consumption of this type of foods, persons from larger families appreciated chiefly the practical aspects connected with purchasing them, i.e. saving time and being less involved in preparation of meals. Among the risks resulting from their consumption, the respondents mentioned mainly their reduced biological activity and vitamin content, as well as worse digestibility of ready-made products $^{2}$.

2 Research concerning the preferences and attitudes to convenience food was also conducted by, e.g. K. Mojka (2012), M. Nowak and T. Trziszka (2006), G. Adamczyk (2004), M. Buckley, C. Cowan and M. McCarthy (2007), M. De Boer et al. (2004). 


\subsection{Functional food}

The past few years have seen considerable interest in bromatology, an interdisciplinary science concerned with the impact of food and diet on consumers' health. The influence of proper nourishment on the state of health of an individual is increasingly appreciated nowadays, hence the growing importance of functional foods [Chłopicka, 2008, p. 249].

Numerous authors have recently discussed the topic of functional foods. Therefore, many definitions of this type of food can be cited. For Thompson and Mougan [Thompson and Mougan, 2008, pp. 61-73], it is food that contains nutrients and other components that may have a direct influence on one's health. According to the definition of the National Institute of Nutrition, functional food means either food or its ingredients that have a positive impact on one's health by reducing the incidence of some diseases or other ailments [Doyon and Lanrecque, 2008, p. 1134]. Brecic, Gorton and Barjolle [Brecic, Gorton and Barjolle, 2012, pp. 662-675] claim that it is modified food or its components that, apart from the nutrients present in traditional food, also have properties which provide additional health benefits. One of the most complex definitions was presented by Korthals [Korthals, 2002, p. 316], who classified food as functional if it was possible to observe its positive influence on at least one target function of the organism, by improving the state of health, well-being or by minimizing the risk of the occurrence of some diseases, including civilization diseases. A similar attitude is expressed by Pieszka and Pietras Pieszka and Pietras, 2010, pp. 83-103], who support the definition proposed by the European Commission in 1998: "A food can be regarded as 'functional' if it is satisfactorily demonstrated to affect beneficially one or more target functions in the body, beyond adequate nutritional effects, in a way that is relevant to either an improved state of health and well-being and/or reduction of risk of disease." Doyon and Labrecque [Labrecque, 2008, p. 1134] emphasize that it is the form of functional foods that is their essential characteristic because they do not come in pills or capsules, but resemble traditional foods, although modified or enriched with an appropriate amount of nutrients.

There are a number of classifications of functional foods. They can be divided, for instance, according to the type of biological impact they have on an organism:

- foods reducing the risk of cancer, cardiovascular disease, and osteoporosis,

- foods with properties ensuring proper functioning of the digestive tract,

- foods for persons under excessive stress.

Functional foods can also be classified depending on their purpose: i.e. foods for pregnant women, children, adolescents, sportsmen, or elderly people. Another classification includes: natural foods (rich in a certain nutrient), enriched foods (modified by adding health-enhancing ingredients), and foods devoid of antinutrient components [Pieszka and Pietras, 2010, pp. 83-103]. Koziołkiewicz [Koziołkiewicz, 2009, p. 11] observes that functional foods more and more frequently include products that contain n-3 polyunsaturated fatty acids, polyphenols, strains of lactic acid bacteria, or fiber. 
According to Voinea [Voinea, 2011, p. 131], interest in functional foods can be traced back to as early as $400 \mathrm{BC}$, to the times of Hippocrates, who said: "Let food be your medicine and medicine be your food". The modern concept of this type of food was developed by the Japanese in the 1980s. The first product from the category was the drink "Fibe Mini", enriched with added fiber.

The market of functional foods is a new and modern segment that over the past few years has been considered the most rapidly developing sector of the global food market. In 2014, Tomaszewska et al. [Tomaszewska et al., 2014, p. 295] stated that, on a global scale, in the year 2000, the value of this market amounted to $30 \mathrm{bln}$ USD, in 2008 it increased to 80 bln USD, whereas in 2015, it reached 130 bln USD. Functional food produced in the USA (35\% of the market), and in Japan (25\%) accounted for the largest share of this market. In Europe, it stood at 10\%. Dairy products comprise the largest (38\%) segment of functional foods on a global scale. In the United States, on the other hand, the market of functional foods is dominated by beverages, which constitute as much as $50 \%$ of this market. In Poland, the most popular functional products are cereals, probiotic yoghurts, isotonic and energy drinks, and juices.

Górecka et al. [Górecka, Czarnocińska, Idzikowski, Kowalec, 2009, pp. 320-326] conducted research ${ }^{3}$ concerning the attitudes of adults towards functional foods, depending on their age and sex, which showed that this type of food is more frequently purchased by women than men. The research did not reveal any essential relationship between the age of the respondents and the purchase of functional foods. A vast majority of the respondents admitted that the prices of this type of foods were too high, whereas the variety on offer fairly limited. The most frequently indicated brand names of functional products in Poland included: Activia, Flora Pro-activ, Benecol, and Jogobella. Additionally, it was demonstrated that the older age and female sex of the studied adults were associated with greater likelihood to select health-beneficial products.

Also Filipiak-Florkiewicz et al. [Filipiak-Florkiewicz, Florkiewicz, Topolska, Cabała, 2015, pp. 166-175] surveyed the opinions of customers of specialty food shops as regards functional food. It was proven that most respondents were familiar with the concept of functional food and had consumed it in the past. Almost one half of those interviewed noticed its beneficial influence on their organisms. A vast majority of the respondents declared that functional products, particularly ones with reduced content of fat, cholesterol and sugar, were needed on the market. In this sector, purchasers expect mostly bread products, but also dairy products and drinks. When selecting foods, the interviewed consumers took into consideration mostly

3 The study comprised 935 adults aged from 20 to 70, inhabitants of Wielkopolskie and KujawskoPomorskie Voivodeships. 
their quality and price. More than $50 \%$ of them stated they would willingly try a new product with proven health-enhancing properties 4 .

\subsection{Specialized gastronomic services}

The development of technologies and the Internet have contributed to the emergence of a new form of food distribution. Consumers can purchase it on dedicated online platforms. Despite numerous misgivings related to the quality of received goods, payment security, and loss of anonymity [Cyrek, 2013, p. 107], the purchasers who decide to buy food online, continuously increase the frequency of purchases and the value of transactions [Grzywińska-Rapca, Grzybowska-Brzezińska, 2016, p. 470]. The results of the research regarding the Polish e-commerce market from 2014 show that online purchases are made by 24\% of Internet users. One in three declared the intention to continue doing so in the future. An analysis conducted by the consulting company Ernst \& Young implies that in 2020 as much as $10 \%$ of food shopping will be done via the Internet [Pochron 2015, p. 45].

Zalega [Zalega, 2013, p. 14] believes that consumers increasingly often use the professional services of catering companies when organizing family reunions, First Communion dinner parties, or other religious occasions. Gębski, Kosicka-Gębska and Tul-Krzyszczuk note that there is a growing demand for take-away food ordered over the phone or via Internet. As a result, more and more companies provide such services. Usually they do not have their own restaurants but are focused on attracting customers to traditional eating places. In Poland, the most wellknown services of this type are: Pyszne.pl, Pizzaportal.pl, Foodpanda.pl, or Skubacz.pl. It is worth emphasizing that many of them offer the possibility of ordering food to be further prepared by the consumer. Busy persons who enjoy cooking receive a box including necessary ingredients (previously washed and chopped) and a recipe for a dish selected from the offer. There is also the possibility of ordering meals adjusted to the diet, food intolerances, or allergies of consumers.

In response to the needs of consumers as regards diversification and the desire to search for new experiences, food companies compete with one another by offering innovative solutions to create value for customers. Consumers are attracted by extraordinary locations, decor, arrangements, or menus the purpose of which is to stimulate their imagination and ensure extraordinary sensations and emotions [Mazurek-Lopacińska, 2011,p. 53]. As an example can serve numerous museums devoted to culinary theme, such as the Living Museum of Gingerbread in Torun, which offers a hands-on approach (the opportunity to operate machines, touch the exhibits, or take an active part in the process of producing food) [Stasiak, 2015, pp. 136-137], such non-conventional restaurants as Restauracja Więzienie (The Prison) in Lublin, with cells and barred windows, or the Dark Restaurant in Poznań, where

4 Research on the attitudes towards functional food was conducted also, among others, by K. Gutkowska et al.. (2014), M. Jeżewska-Zychowicz et al. (2012), A. Filipiak-Florkiewicz et al. (2016), and W. Verbeke (2005). 
customers remain in total darkness and waiters wear night-vision goggles [Kowrygo, Stangierska, 2012, p. 500].

Also street food, although present in the market for a long time, is gaining popularity in developed countries. Lin and Yamao [Lin, Yamao, 2014, pp. 1-10] notice that it has become one of the most important hallmarks of city life, especially in developed economies, and is a major tourist attraction. Because of their fast lifestyles and long working hours, consumers are more likely than ever to turn to this form of consumption. One type of street food are food trucks, i.e. large vehicles with necessary equipment for cooking and serving meals. Although food trucks date back to as early as the 18th century [Hawk, 2013, p. 11], owing to the rising number of mass sports and cultural events attracting crowds of people to places without catering facilities, they have become particularly popular nowadays. The main function of food trucks is to promote the cuisine of other countries, hence in Poland the numerous trucks offering Mexican, Cuban, Japanese, or Belgian food [Gwiazdowska K., Kowalczyk A., 2015, pp. 10-13].

Another way to satisfy the needs of today's customers is to enable them to organize a party by themselves and invite guests to cook together. Conventional eating out is often being replaced by participation in dining clubs within the framework of which meetings are organized in private flats, houses or restaurants. The purpose of these clubs is to allow their members to meet new people, and consume fancy food in a homey atmosphere [Mazurek-Łopacińska, 2011, p. 53].

\section{Conclusion}

The aim of this paper is to discuss - on the basis of secondary sources of information - convenience foods and functional foods, as well as selected gastronomic services as examples of innovations in the food market.

The conducted analysis has revealed that both the needs and expectations of consumers have undergone considerable changes. Because of their active lifestyles and greater ecological and health awareness, contemporary buyers seek user-friendly, time-saving and health-improving alternatives. Additionally, they pay more attention to emotions associated with consumption of food.

As the literature review shows, product innovations in the food market, are a response to these new food needs of consumers. The author chose to focus on convenience and functional foods, as well as special gastronomic services, which largely differ from traditional products available, providing consumers with greater benefits. Furthermore, companies providing gastronomic services ensure unique sensations and emotions by offering extraordinary locations, menus, or ways of serving meals.

Since the needs of buyers are subject to modifications, in order to maintain a competitive advantage in the market, companies are compelled to conduct regular analyses of customer preferences and introduce innovative solutions adjusted to these expectations. Therefore, particular importance is attached these days to the 
profiles of the purchasers of food products and gastronomic services - a topic likely to become the subject of further research.

\section{References}

Adams J., Goffe L., Brown T., Lake A., Summerbell C., White M., Wrieden W., Adamson A., 2015, Frequency and socio-demographic correlates of eating meals out and take-away meals at home: cross-sectional analysis of the UK national diet and nutrition survey, waves 1-4 (2008-12), International Journal of Behavioral Nutrition and Physical Activity, DOI 10.1186.

Autio M., Collins R., Wahlen S., Anttila M., 2013, Consuming nostalgia? The appreciation of authenticity in local food production, "International Journal of Consumer Studies", 37.

Babicz-Zielińska E., Jeżewska-Zychowicz M., Laskowski W., 2010, Postawy i zachowania konsumentów w stosunku do żywności wygodnej, Żywność. Nauka. Technologia. Jakość, 4(71).

Chłopicka J., 2008, Gryka jako żywnośc funkcjonalna, „Bromat. Chem. Toksykol.”, XLI, 3.

Cyrek P., 2013, Stosunek klientów do internetowych zakupów żymości, Zeszyty Naukowe SGGW w Warszawie, Polityki Europejskie, „Finanse i Marketing”, 09(58).

Czupilowska K., 2014, Innowacje produktowe w swietle preferencji konsumentów w segmencie czekolady na praykeładzie rynku FMCG, „Studia i prace wydziału nauk ekonomicznych i zarządzania”, nr 38, t. 1.

Doyon M., Labrecque J., 2008, Functional foods: a conceptual definition, British Food Journal, vol. 110, no. 11.

Dziok, B., 2014, Etnocentryzm konsumencki na rynku produktów \&̇ywnościowych, jako strategia marketingowa producentów żywności, „Marketing i Rynek”, 6 (CD).

Euromonitor International 2012 Home Cooking and Eating Habits: Global Survey Strategic Analysis.

Filipiak-Florkiewicz A., Florkiewicz A., Topolska K., Cabała A., 2015, Żywnośc Funkcjonalna (prozdrowotna) w opinii klientów specjalistycznych sklepów z żywnościa, „Bromat. Chem. Toksykol.", XLVIII, 2.

Gardocka-Jalowiec A., 2017, Zmiany struktury potrzeb a rozwój kapitału ludzkiego, „Konsumpcja i Rozwój”, 18(1).

Gębski, J., Kosicka-Gębska, M., Tul-Krzyszczuk, A., 2017, Wptyw Internetu na zachowania wspótçesnych konsumentów wobec żywności, „Handel Wewnętrzny”, 2(367).

Goetzke B. I., Spiller A., 2014, Health-improwing lifestyles of organic and functional food consumers, "British Food Journal", vol. 116, no. 3.

Górecka D., Czarnocińska J., Idzikowski M., Kowalec J., 2009, Postawy osób dorostych wobec żywności funkcjonalnej w zależności od wieku i ptci, „Żywność. Nauka. Technologia. Jakość", 4(65).

Grzywińska-Rappca M., Grzybowska-Brzezińska M., 2016, Determinanty e-zakupów na rynku śywności, Roczniki Kolegium Analiz Ekonomicznych, Szkoła Główna Handlowa, nr 40. 
Gulbicka B., Kwasek M., 2007, Wplyw globalizacji na wyšnwienie ludności w Polsce, Ekonomiczne i Spoteczne uwarunkowania rozwoju polskiej gospodarki sywnościowej po wstapieniu Polski do Unii Europejskiej, Instytut Ekonomiki Rolnictwa i Gospodarki Żywnościowej - Państwowy Instytut Badawczy, Warszawa.

Gwiazdowska K., Kowalczyk A., 2015, Zmiany upodoban symienionych $i$ zainteresowanie kuchniami etnicznymi - praycrynnek do turysty)ki (kulinarnej?), „Turystyka Kulturowa”, nr 9.

Hanus G. 2017, Żywność wygodna i funkecjonalna - sžansa çy zagrożenie dla wspótczesnego konsumenta, Człowiek wobec zagrożeń współczesności, Wydawnictwo Naukowe Wyższej Szkoły Biznesu i Nauk o Zdrowiu, Łódź.

Hawk Z. A., 2013, Gourmet food trucks: an ethnographic examination of Orlando's food truck scene, Department of Anthropology, College of Science, University of Central Florida, Orlando, FL, praca magisterska: [http://sciences.ucf.edu/anthropology/ wpcontent/uploads/sites/19/2013/09/Hawk_Zachart.pdf, retrieved: 15.07.2017.

Kondratowicz, J., Burczyk, E., Janiak, M., 2009, Liofilizacja jako sposób utrwalania ṡynności, Chłodnictwo: organ Naczelnej Organizacji Technicznej, 44(1-2).

Korthals M., 2002, The Struggle over Functional Foods: Justice and the Social Meaning of Functional Foods, "Journal of Agricultural and Environmental Ethics", 15.

Kowalczuk I., 2009, Innowacyjność produktowa pręedsiębiorstw branşy spośywczej, Zeszyty Naukowe SGGW w Warszawie, „Ekonomika i Organizacja Gospodarki Żywnościowej", nr 75.

Kowrygo, B., Stangierska, D., 2012, Rozwój przedsiębiorczości na prayketadzie ustug gastronomicznych, Zeszyty Naukowe Uniwersytetu Szczecińskiego, „Ekonomiczne Problemy Usług", 98.

Koziołkiewicz M., 2009, Koncepcje nutrigenomiki, „Biotechnologia”, nr 4(87).

Krełowska-Kułas, M., 2005, Badania preferencji konsumenckich šywności wygodnej, „Zeszyty Naukowe Akademii Ekonomicznej w Krakowie", nr 678.

Krzysztoń A., 2014, Analiza stanu zaspokojenia niektórych potrzéb spotecznych w zależności od źródta utraymania gospodarstwa domowego, „Acta Universitatis Nicolai Copernici. Nauki Humanistyczno-Społeczne. Ekonomia”, t. 45, nr 2.

Maddock S., Hill B., 2016, Bagels and doughnuts ... round food for every mood food advertising discourses, "British Food Journal", vol. 118, issue 2.

Makała H., 2002, Żywność nygodna w przemyśle miessnym. Trendy i oczekiwania konsumenta, „Gospodarka Mięsna”, nr 11.

Makała H., 2013, Trendy w produkcji synwności uygodnej i jej pryykłady zastosowania w turystyce - mybrane aspekty, „Zeszyty Naukowe, Turystyka i Rekreacja”, nr 2(12).

Mańkowska-Wróbel L., 2014, Ekologične warunkowania zachowań konsumenckich, „Handel Wewnętrzny", nr 1(354).

Mazurek-Lopacińska K., 2011, Postmodernistyczna kultura konsumpcyjna w ksztattowaniu popytu i stylów śycia wspótcžesnego, „Konsumpcja i Rozwój”, nr 1.

McLean-Meyinsse P., Taylor S., Gager J., 2015, Self-Reported Consumption of Fast-Food Meals by University Students, "Journal of Food Distribution Research", vol. 46, issue 1.

Morse K., Driskell J., 2009, Observed sex differences in fast-food consumption and nutrition self-assessments and beliefs of college students, "The FASEB Journal", vol. 29. 
Muhammada S., Fathelrahmanb E., Ullah Tasbih Ullah R., 2015, Factors Affecting Consumers' Willingness to Pay for Certified Organic Food Products in United Arab Emirates, "Journal of Food Distribution Research", vol. 46, issue 1.

Olejniczak, T., 2011, Zakupy innowacji produktowych na rynku s̀ynnosici - w swietle badań konsumenckich, „Zeszyty Naukowe Wyższej Szkoły Bankowej we Wrocławiu”, $\mathrm{nr}(25)$.

Pochroń J., 2015, E-commerce jako ciagle rozwijajacy sie rynek na prayktadzie internetonych skelepón z. symnościa [w:] Innowacyjne driatania w obszarze zarzqdzania $i$ marketingu, A. Wadlewski, A. Modliński (red.), Wydawnictwo Uniwersytetu Lódzkiego.

Rachocka, J., 2003, Dekonsumpcja, domocentryzm, Ekologizacja sycia-nowe tendencje konsumenckie w rozwinietych gospodarkach rynkonych, [w:] Problemy globalizacii gospodarki, Bernat T. (red.), Polskie Towarzystwo Ekonomiczne, Szczecin.

Richardson A. J., 2003, The importance of omega-3 fatty acids for behaviour, cognition and mood, "Scandinavian Journal of Nutrition", nr 47(2).

Saeed A., Humayun A., Raana T., 2015, Depression the Hidden Iceberg: Role of Nutrition \& Dietary, "IOSR Journal of Nursing and Health Science", vol. 4, issue 5, ver. I.

Sojkin B., 2009, Konsument wobec innowacji produktowych na rynku siswności, Wydawnictwo Uniwersytetu Ekonomicznego w Poznaniu.

Stasiak, A., 2015, Rozwój turystyki kulinarnej w Polsce, Kultura i turystyka - wokót wspólnego stołu, Regionalna Organizacja Turystyczna Województwa Lódzkiego.

Szymańska A. I., 2012, Innowacyjność produktowa przedsiębiorstw produkcyjnych a preferencje konsumentów, „Prace Komisji Geografii Przemysłu Polskiego Towarzystwa Geograficznego", nr 20.

Tomaszewska M., Bilska B., Grzesińska W., Przybylski W., 2014, Żymność funkcjonalna jako mo:̧liwość rozwoju polskich firm spożywczych, „Roczniki Naukowe Stowarzyszenia Ekonomistów Rolnictwa i Agrobiznesu", nr 16(3).

Voinea L., 2011, Impact of food supply diversification trends on the consumers' quality of life, "Management \& Marketing Challenges for the Knowledge Society", vol. 6, special issue.

Zalega T., 2011, Sposiycie synnności w gospodarstwach domonych z osobami bezrobotnymi w wojewódžtwie mazowieckim, „Zeszyty Naukowe SGGW - Ekonomika i Organizacja Gospodarki Żywnościowej”, nr 93.

Zalega, T., 2013, Nowe trendy $i$ makrotrendy w zachowaniach konsumenckich gospodarstw domonych w XXI w., „Konsumpcja i Rozwój”, nr 2.

Zuchowski I., Brelik A., 2007, Wybrane zagadnienia teorii zachowania konsumenta, „Zeszyty Naukowe Ostrołęckiego Towarzystwa Naukowego", nr 21. 